\title{
UTILIZING STAKEHOLDERS ANALYSIS ON SUSTAINABLE ORGANIC FARMING IN WEST JAVA: THE CASE OF CISARUA ORGANIC FARMING
}

\author{
Sekar Wulan Prasetyaningtyas ${ }^{* 1}$, Sobir ${ }^{* *}$, Aji Hermawan ${ }^{* * *}$, and M. Syamsul Maarif ${ }^{* * *}$ \\ *) International University Liaison Indonesia (IULI) \\ MyRepublic Plaza 5th Floor Green Office Park Tangerang Selatan, Tangerang 15345 \\ ${ }^{* *)}$ Department of Agronomy and Horticulture, Faculty of Agricultural, IPB University \\ J1. Meranti, IPB Darmaga Campus, Bogor 16680 \\ ${ }^{* * *}$ School of Business, IPB University \\ Jl. Raya Pajajaran, Bogor 16151
}

\begin{abstract}
There has been an increase in demand for organic products in Indonesia along with the incessant slogan of healthy living. In terms of small farmers, organic farming is proven to provide increased income, unfortunately there is no clear system and strategy in developing organic agriculture in Indonesia. The purpose of this research was to understand the role of key stakeholders in Cisarua Horticulture Organic Farming. Stakeholder analysis used in this research to get knowledge about the actors, their behavior, relationships and their influence on decision - making processes. The information is used to develop the farm strategies, to reach the farm goals and to assess the feasibility of policy directions. The methodology used is the Soft System Methodology (SSM). SSM is an organizational process modeling method that can be used for general problem resolution and change management. Rich picture, Root definitions and conceptual model were presented in the paper. Data were taken using focus group discussion and in-depth interviews with the farm staffs, farmers of the sustainable horticulture organic farming farm in Cisarua, Indonesia, and national organic farming association. From Stakeholders analysis, four main results were obtained: identifying the relationship among stakeholders; conflicts among them; the stakeholders' role in farm; and the stakeholders' interest towards farm program. In conclusion; focusing on one hauler only, investing in seed horticulture products, improving the quality of horticulture products, and mentoring for small-scale farmers were identified as a critical action for the strategy in the organic farming farm in Cisarua, Indonesia. The policy implications of this research are basically to see the contribution of actors in making a strategy.
\end{abstract}

Keywords: organic farming, soft system methodology, stakeholders' analysis, horticulture, sustainable

\begin{abstract}
Abstrak: Terjadi peningkatan permintaan produk organik di Indonesia seiring dengan gencarnya slogan hidup sehat. Dari segi petani kecil, pertanian organik terbukti memberikan peningkatan penghasilan, sayangnya belum ada sistem dan strategi yang jelas dalam mengembangkan pertanian organik di Indonesia. Tujuan penelitian ini adalah untuk memahami peran pemangku kepentingan utama dalam Pertanian Organik Hortikultura Cisarua. Analisis stakeholder yang digunakan dalam penelitian ini untuk mendapatkan pengetahuan tentang aktor, perilaku mereka, hubungan dan pengaruh mereka pada proses pengambilan keputusan. Informasi ini digunakan untuk mengembangkan strategi pertanian, untuk mencapai tujuan pertanian dan untuk menilai kelayakan arah kebijakan. Metodologi yang digunakan adalah Soft System Methodology (SSM). SSM adalah metode pemodelan proses organisasi yang dapat digunakan untuk resolusi masalah umum dan manajemen perubahan. Gambaran kaya, definisi Root dan model konseptual disajikan di koran. Data diambil dengan menggunakan diskusi kelompok fokus dan wawancara mendalam dengan staf pertanian, petani pertanian pertanian organik hortikultura yang berkelanjutan di Cisarua, Indonesia, dan asosiasi pertanian organik nasional. Dari analisis Stakeholder, empat hasil utama diperoleh: identifikasi hubungan di antara para pemangku kepentingan; konflik di antara mereka; peran para pemangku kepentingan di pertanian; dan minat pemangku kepentingan terhadap program pertanian. Fokus pada satu pengangkut saja, investasi dalam benih hortikultura, meningkatkan kualitas produk hortikultura, dan mentoring bagi petani skala kecil diidentifikasi sebagai tindakan penting untuk strategi dalam pertanian pertanian organik di Cisarua, Indonesia. Implikasi kebijakan dari penelitian ini pada dasarnya untuk melihat kontribusi aktor dalam pembuatan sebuah strategi.
\end{abstract}

Kata kunci: pertanian organik, metodologi sistem lunak, analisis pemangku kepentingan, hortikultura, keberlanjutan

\footnotetext{
${ }^{1}$ Corresponding author:

Email: sekarwprasetya@gmail.com
} 


\section{INTRODUCTION}

In recent years, environmental issues have become the focus of society. People started to realize the dangers posed by the use of chemicals, one of which is used in the business of agriculture. The use of non-chemical materials received attention to be used in agricultural activities, known as organic farming. Indonesia as one of the developing and emerging economy countries with approximately 252 million in population in 2015 and economic growth of $5.2 \%$ per annum has the potential to be both of the largest producers and market for the organic products.

Indonesia Central Bureau of Statistics (2015) stated that Indonesia has 11.94 million hectares of vacant land. Parlyna \& Munawaroh (2011) predicted that organic food export revenues from the vacant land in Indonesia are estimated at US\$100 billion per year. In general, the average income that will be obtained from organic farming is around US $\$ 6,000$ per hectare. In terms of price, organic products in the international market range from 5-10 times the price of ordinary products. At a macro level, this can drive the economy. In addition to economic benefits, the development of organic products is labor-intensive. The creation of these new jobs, contributes to rural social and economic growth.

The organic agriculture movement in Indonesia emerged as part of the development of the world organic movement. In 2000, the Department of Agriculture made a policy on organic farming, called "Go Organic 2010". Under the policy, the Indonesian Organic Certification Agency (B1OCert) was established as an organic certification body by 33 Indonesian organic NGOs, researchers, the private sector and farmer groups in 2002 (BIOCert, 2018). Over time, the "Go Organic" movement has not yet had a real effect on increasing the amount of land and organic agricultural production in Indonesia, even though the potential for organic land is very large.

David and Ardiansyah (2016) mentioned that there are a small number of publications focusing on organic agriculture in Indonesia. The most investigative topic was soil and water resources in organic agriculture. This may be related to the fact Indonesia lies within the tropical climate zone where the soil and water have a significant effect on organic agriculture. Nevertheless, there are still many aspects of organic agriculture especially in business and management areas that have not yet been addressed.

Empirical data shows that most of the organic farms in Indonesia are managed using a cooperative farm model. The co-operative model usually applied in the area which is considered marginal, economically low and the work skills of the people are also considered low. The farm model has been used successfully in developed countries like Spain and Italy, but not in some of the developing countries like South Africa and Asia (Hammond and Luiz, 2016). In Indonesia, the most common type of farm cooperative model is Koperasi Unit Desa or Village Unit Cooperative (VUC). VUC is a type of cooperative which manages several businesses comprising of villagers which generally located in a district. The presence of VUC in each district aims to boost economic growth by income distribution through rural areas based on the balance of social justice (Riswan et al. 2017).

In this 4.0 industrial era, farm movement in Indonesia especially in organic farming facing great challenge due to the rapid change in the global economy and open market competition. There is no clear strategy yet in managing the organic farms in Indonesia. Apart from that, the stakeholders in the farm has not been defined clearly as well. This stakeholder mapping is very important in making the strategy works since stakeholders are the key players in the organization, the 'machine' that can help organization reach its goals. One of the tools in stakeholders' mapping is by using stakeholder's analysis. Stakeholder analysis has never been done in organic agriculture research in Indonesia, however Hani and Tamam (2016) have conducted this stakeholder analysis to analyze the response of stakeholder on the development strategy of sugarcane agribusiness in a dry land. This research was conducted in three districts of East Java.

Since stakeholders' analysis (SHA) is a powerful tool to help farm members identify and prioritize stakeholders who can have an impact on farm success, it is very important to have this stakeholders' analysis on organic farm in Indonesia. Kennon et al. (2009) emphasized that SHA is an essential starting place for understanding critical stakeholders and is the first step for developing engagement strategies for building and maintaining the networks that are necessary for 
the delivery of successful project outcomes. Based on problem identified, wasthis research aimed to map the stakeholders in one of the successful organic farms in Indonesia, by utilizing the stakeholder's analysis using Soft Systems Methodology (SSM) in the organic horticulture farming farm in Indonesia.

Stakeholders, both individuals and groups, are considered important in a system because stakeholders can influence and can also be influenced in making decisions. This relates to the power, resources, information, expertise and the needs of each of these stakeholders (Vairo et al. 2009). Ristianingrum et al. (2016) stated that, main problems in Indonesia's organic farming are mostly related to stakeholders and support system. Stakeholder analysis is one of the approaches that can be used to analyze the relationship between stakeholders. It can identify a project's key stakeholders, assess their interests and needs, and clarify how these may affect the project's viability. From this analysis, program managers can make plans for how these aspects will be addressed (Allen and Kilvington, 2010). The objective of SHA is to understand the interests of the different parties involved, and to find a compromise between the potential conflicts identified during the investigation (Varvasovszky and Brugha, 2000; Missonier and Loufrani-Fedida, 2014).

Different stakeholders often have different views on exactly what and how to address problems in organic horticultural farm farming. Therefore, correct methods are needed to let stakeholders identify issues in organic horticulture farm, which maybe occur not only because of the technical problems but also socio-economic problems. One of the methods that can be used in stakeholder analysis is Soft System Methodology (SSM). SSM enables problem solving through dialogue and qualitative methods, and it explicitly considers aspects such as ethics, sustainability, and human values to better understand and structure the problem situation, support the participants in making decisions and reaching agreement on action plans (Tavella and Hjortsø, 2012). SSM is presented as a new problem-solving approach which is useful to the organic farming sector in Indonesia.

Regarding strategy making, the issue of sustainability is important because a strategy must be able to foster the development of current conditions without disrupting future interests (Bahar, 2007). Stefan and Paul (2008) also emphasize that creating sustainable strategies can lead to improved relationships with stakeholders, reduce input costs, and increase revenue through better access to markets and the possibility of different products and new technologies. Although there are variations in definitions, there are three themes that are interrelated at the core of sustainability: environmental integrity, social justice, and economic prosperity. Amewaka (2010) research on sustainability indicators in developing countries, especially at the level of small businesses, concludes that the three indicators mentioned above are measurable, integrative, and holistic indicators. Waney et al. (2014) in developing sustainability indicator for farm level in Indonesia stated that at least four economic indicators can be used, they were farm productivity (yield), product (vegetables) quality, cost of production and producers-buyers relationship (relations with market participants and consumers). In terms of social justice, what is highlighted is about empowering farmers and developing a farming culture in the countryside, while in terms of the environment, the most widely used indicator is the quality of air, water and soil.

\section{METHODS}

This research was using primary and secondary data. The primary data were obtained by conducting interviews and focus group discussion (FGD). The secondary data were obtained through a literature study of a number of scientific publications such as books, research reports, research journals, theses, and dissertations. Articles in relevant print and electronic media were also used to support research.

This research was an exploratory research, using qualitative approach. Multiple stakeholders in the farm area (farmers, farm staffs, Organic Farming Association, and regulator) were involved in the research. To get some initial information regarding the issues in farms such as roles, leadership, goals; the researcher conducted semistructured, in-depth interviews on 13-15 July 2018, in the Cisarua farm area. Open-ended questions were used to allow the different inputs from the stakeholder. In total, there were eleven interviews conducted. Not all stakeholders that invited were coming due to several problems. Data were taken from five farmers, three staffs from the farm, and three representatives from the Organic Farming Association. All interviews were digitally recorded and transcribed. 
After the interview, the first FGD was conducted on 22 August 2018. Eleven participants; seven farmers, three farm staffs, and one representative from the Organic farming Association, were coming to the FGD. The purpose of the first FGD was to construct the rich pictures. Not all invitees attended the first FGD. A second FGD, which was held on 27 September 2018, was done to show the conceptual models to the stakeholders. This FGD was attended by three farm staff and eight farmers. In this FGDs, participants were identifying several issues in organic horticulture farms such as business strategy in the farm, organic horticulture supply, organic horticulture quality, transport, conflict in communication, and eventually acting to address these issues.

The data will then analysed using Soft System Methodology (SSM). SSM is a qualitative research method based on thinking systems that places importance on meaning, self-reflection, interpretation, human experience, learning and participation (Proches and Bodhanya, 2015). SSM was constructed because there are limitations in the system engineering approach, which insufficient in the social complexity of human situations. Systems engineering is classified as a method of hard systems, whereas SSM focuses on learning rather than designing a solution (Khisty, 1995).

The SSM phases were depicted in Figure 1, started by identifying issues and analyzing cultural and power relations (Checkland and Poulter, 2006). The first phase of SSM is Rich Picture making. Rich pictures can be used to explain the situation by showing the stakeholders and the problems they experienced, as well as the interactions and relations between actors. The second phase of SSM is building the relevant activity models that correspond to a particular worldview, called Root definitions. It identifies the core purpose of the activity system (Checkland and Poulter, 2006). The next phase is making the PQR formula that behaves as a transformation model. The $\mathrm{P}$ is what, $\mathrm{Q}$ how, and $\mathrm{R}$, why. A general model of purposeful activity, known as the CATWOE is then modeled (Checkland and Poulter, 2006). The abbreviation of CATWOE is explained as follow: $\mathrm{C}$ for the Customers who got benefits or victims, A for the Actors, $\mathrm{T}$ for the Transformation, $\mathrm{W}$ for the Worldview, $\mathrm{O}$ for the, and $\mathrm{E}$ for the environmental constraints. After that, the conceptual models are then created. The models are then used to structure debate about the situation. The final stage in the SSM consists of defining and implementing necessary actions with the aim of identifying desirable and culturally feasible changes.

This research was done to create a sustainability strategy in organic farming in Indonesia, by involving the actors in the design, and by considering the sustainability indicators (economic, social, and environmental). The checklist of sustainability framework was created using empirical data from the organic farm to guide the strategy design making. These lists will then be validated by the people involved in the design. The research framework can be seen in Figure 2.

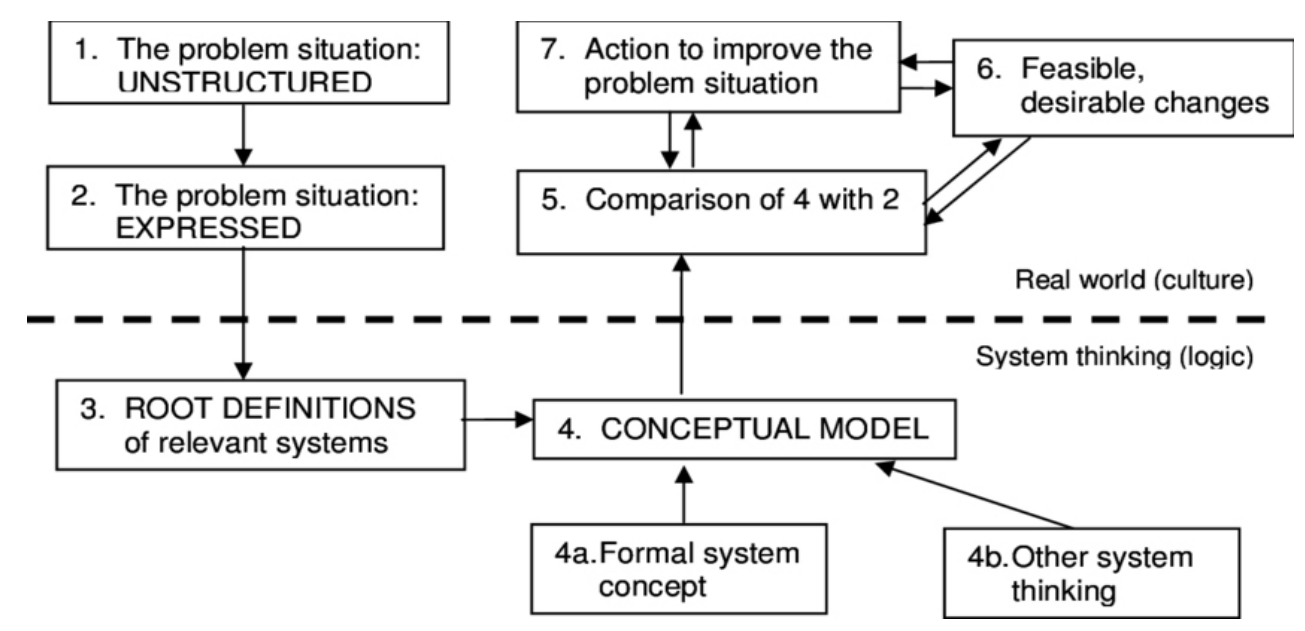

Figure 1. Steps in Soft System Methodology (Checkland and Poulter, 2006) 
(Purpose of control)

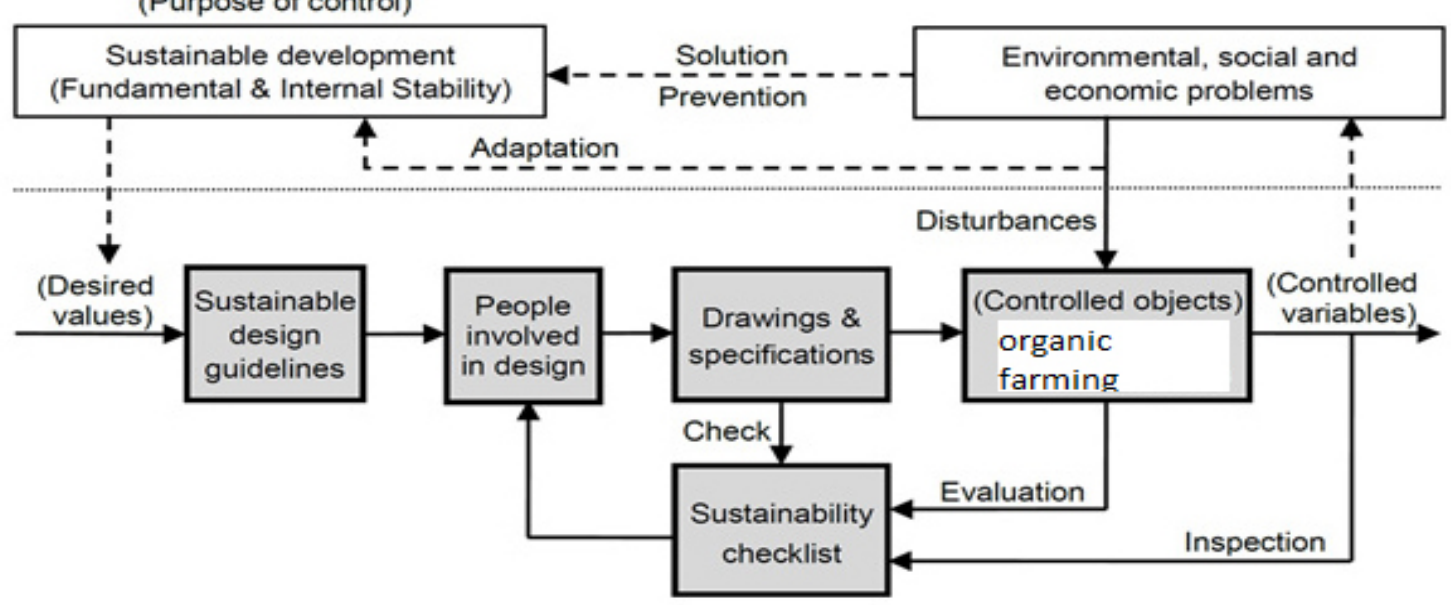

Figure 2. Research framework

\section{RESULTS}

The purpose in the first phase of SSM was to get information regarding the main problems in farm from all perspectives of stakeholders. In this phase, researcher focus in the soft issues in farm such as leadership style, communication, and shared-goals. The next phase is to picture the problem situation, by conducting the first FGD. In this FGD, the participants were asked to use a few words as possible in constructing the rich picture. The purpose was to make the rich picture simple and concise. Tsouvalis and Checkland (1996) stated that a simple rich picture is needed to make all stakeholders from all levels of education to understand the concept.

After the interview, researcher conducted the Focus Group Discussion. The purpose of the first FGD is to identify the stakeholders in farm. Apart from that, the participants also identify the role and concerns. They also drew the connection between the stakeholders. This rich picture was then evaluated at the end of the FGD to allows the mutual understanding between the stakeholders. Stakeholders' concerns were shown in the rich picture using think bubbles and conflicts using crossed line. This phase is crucial because as Brenton (2007) said that rich pictures enable the identification of issues. The process was not smooth due to the culture of Indonesia people that does not want to damage the relationship if they tell the truth. With this condition, the researcher realized that some issues might not have been mentioned by the participants, or they might be not completely honest.
Apart from that problem, through the FGD, the stakeholders realized that one stakeholder might affecting other stakeholder in the system. They also able to picture that some of the fundamental problems in the farm arise because they don't have the skills needed to handle the communication of the diverse stakeholders. Not only the communication, the transparency and the trust were highlighted as something that crucial. The rich picture can be seen in Figure 3.

Based on the rich picture, the farm plays an important role in the organic farm and emphasis on reliable and high-quality of horticulture supply; and farm efficiency. The headquarters oversees the farm, and put a concern in profitability and its shareholders. In terms of farmers, the farm receives products from large-scale, and smallscale farmers.

The benefit of rich picture is because it gives a valuable insight for the researcher regarding the concerns, values, and perspectives of each stakeholders. As seen in Figure 1, large-scale farmers were concerned about yield, efficiency in transport, and profitability meanwhile small-scale farmers about economies of scale and finances. Another benefit from the rich picture because it can identify stakeholders that might not appear from the preliminary interview. In this case, the haulers. The role of the haulers is to transport the horticulture products from the farmers to the farm. Their concerns were mainly about the profitability.

From the rich picture, can be seen also that there are neighborhood farms in the broader area. Farmers could send their products to farm in the neighborhood areas without having extra transport cost. This situation of course will affect the profit of the farm. 


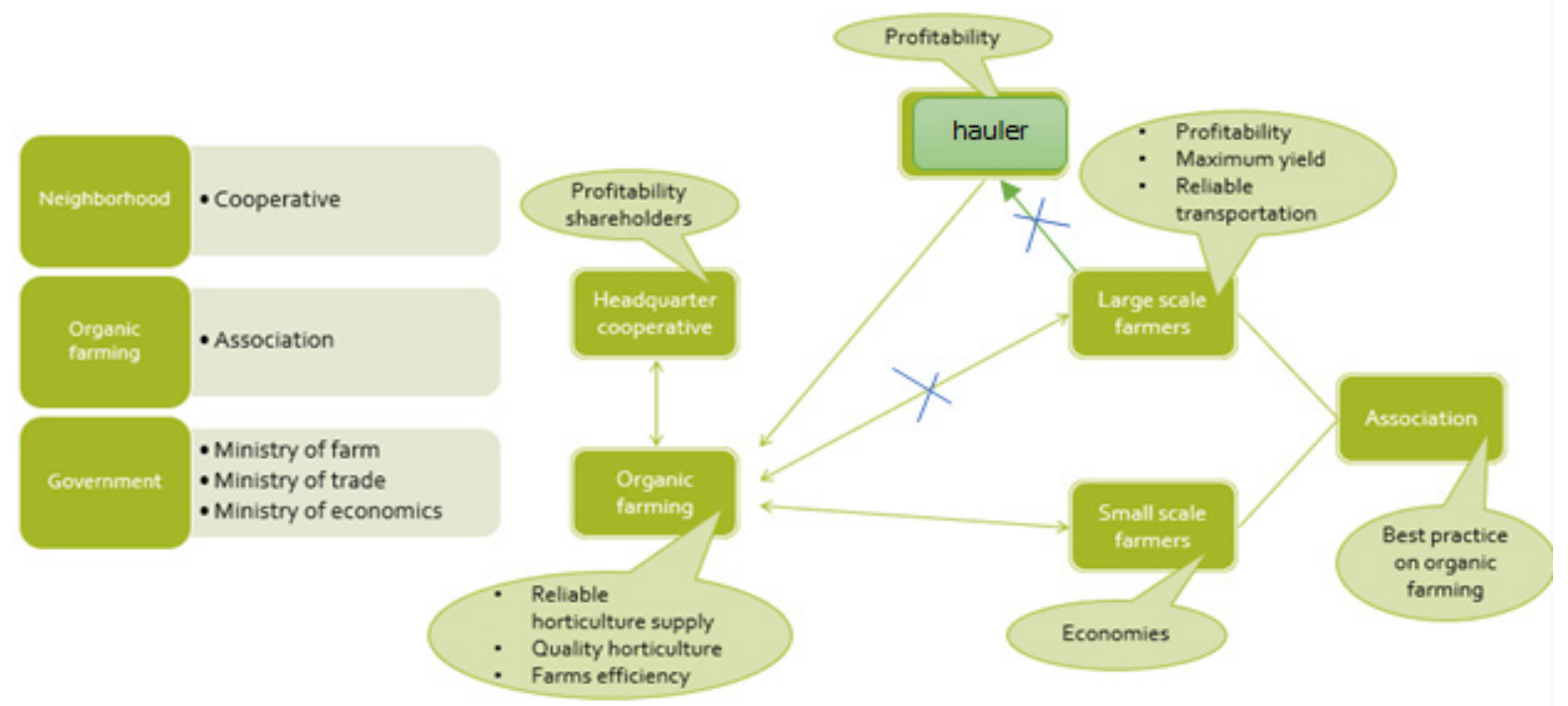

Figure 3. Rich picture in Cisarua organic horticulture farm

Another stakeholder mentioned in the rich picture is The Organic Farming Association. They are important because they involved in the regulation and the certification of organic farming products. Another important stakeholder mentioned in the rich picture is the Government, specifically the ministry of farm, ministry of trade and ministry of economic, although the representatives from the ministries were not coming to FGD. They are important because they are the price controller of the organic horticulture products. They also made regulations which have an impact on the good agricultures' practices in the farms, and how the sale of organic farming is managed. All stakeholders that were involved in the FGD (farmers, staff, and the Indonesia Organic Alliances) agreed that if only the representatives from the regulator were come, the discussion can be more fruitful and substantial for the organic farming strategy development.

Conflict between stakeholders also pictured using crossed line. Conflict happened between the large-scale farmers and the farm, whereas both parties having their own need regarding their well-being. Conflict also happened since the farmers think that the headquarters did not consider the well-being of the farmers due to the transparency of the farm. The farmers did not be wellinformed regarding the condition especially in terms of financial in farm. There is also a perception that farmers did not have power over the farm. These conflicts need to be pointed out clearly as Ndwandwe and Weng (2018) advised that it is critical for stakeholders to display commitment to the survival of the farm area, to focus on enhanced performance against competitors, and to avoid internal conflict. To solve the conflict, all stakeholders agreed that transparency is important and it need to be pointed out and communicated well among the stakeholders especially regarding the financial rights for the farmers.

This conflict not only arise between large-scale farmers and the farm, but also between the large-scale farmers with the haulers. The haulers sometimes late to pick up the products and it can deteriorate the quality of horticulture products, which will give negative effect to both parties. To solve the conflict, all stakeholders agreed that communication is very critical. Leadership also considered as one of the critical factors in the situation.

The next phase of SSM is transforming the rich picture into the relevant system. Checkland (1985) stated that the most critical issues must be selected. Based on the preliminary interviews, five relevant systems were identified. They are: appreciation for the farmers; increasing supply of horticulture products; sustainability of the small-scale farmers; the quality delivery of horticulture products; and good communication among stakeholders. CATWOEs, Root definition, and conceptual models were made for the five systems listed above. The second FGD then done on September 2018 to showed the 5 SSM models to the stakeholders. Participants made their choices by tallying the 5 system. Based on this, the research was then focus on a system for the consistent delivery of 
quality horticulture products. In the farm, the shipping was done by the farm employee, twice a week, to their main office in Jakarta. The refrigerated truck was used to maintain the quality of horticulture products. if there is a product damage due to the shipping process, the customer can immediately send the complaint via telephone or email service to the head office, and the damaged product will be immediately replaced on the next shipment. CATWOE analysis and Root definition was presented below, while the conceptual model for the system was presented in Figure 3.

\section{CATWOE Analysis (Customers, Actors,} Transformation, Worldview, Owners, and Environment) for the consistent delivery of quality horticulture products:

\section{C : Farm, farmers}

A : Haulers, farmers, farm

$\mathrm{T}$ : Consistent delivery of quality horticulture products according to the defined rate able daily deliverables

$\mathrm{W}$ : Follow good agricultural practices and ensure efficient transport to the farm to enable the consistent delivery of quality horticulture products
$\mathrm{O}:$ Farmers, haulers

E : Available input resources, weather

Root definition for the consistent delivery of quality horticulture products:

A farmer- and hauler-owned system, operated by haulers, farmers, and the farm, to ensure consistent delivery of quality organic horticulture products according to the agreed rate able daily deliverables, by following good agricultural practices and ensuring efficient transport to the farm to ensure the consistent delivery of quality organic horticulture products, within the constraints of the availability of input resources and weather.

The second FGD was done to present the conceptual model in Figure 4 to the participants, where they were asked to compare the model with the real world. Khisty (1995) stated that, the most important thing about presenting the conceptual model is that how researcher can show descriptions that arrived from multiple views of the stakeholders' interpretations.
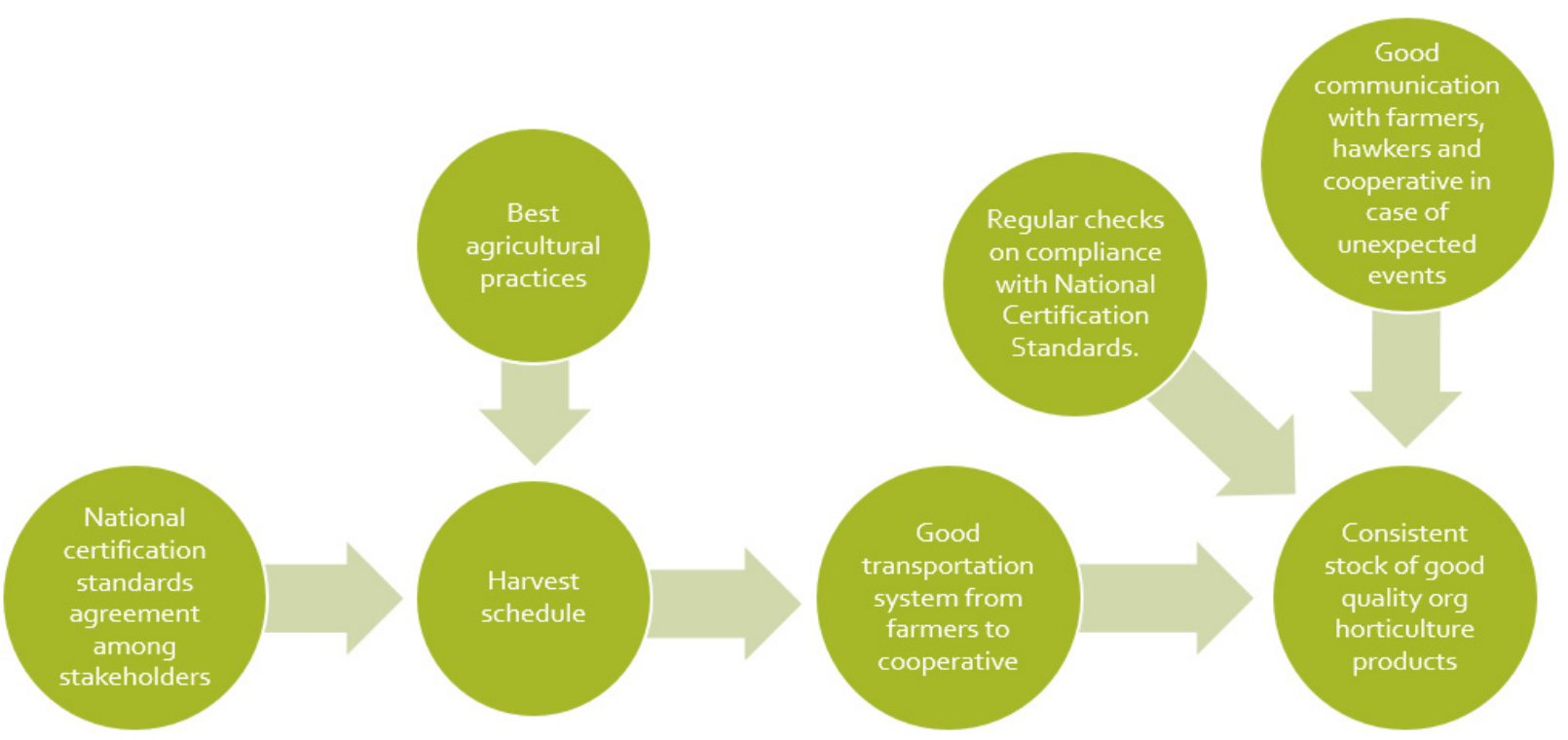

Figure 4. Conceptual model for a system for the consistent delivery of quality organic horticulture products 
In discussing the conceptual model, participants stated that the Organic farming association plays an important role in ensuring quality horticulture products by maintaining best practice in organic agriculture, in forms of internal certification. The role of hauler also critical in ensuring quality of horticulture products by committing the schedule of pick-up and delivery of the products. Participants stated that at this moment there were at least 8 (official and unofficial) haulers in the farm area, and that ideally there should only be one or two official's haulers. Through this research, we can see the relationship between each of the stakeholders in farm level, and how this relationship affects the farm operational activities. One of the important parameters of stakeholder analysis is how the effectiveness of relations between stakeholders. Researches on big public infrastructural projects have shown that project success is now dependent on the perception and satisfaction of the stakeholders than mere conventional iron triangle (cost, quality, time) (Toor, 2010).

Based on the rich discussions, researcheralso noted some possible actions that stakeholders could make to bring the improvement in the farm. These actions included investing in seed horticulture products, improving the quality of horticulture products, mentoring for small-scale farmers and introducing one hauler only. Participants also mentioned that the attendance of key decision makers, such as the farm executive (HQ) and farm leaders at the workshop would have given such valuable input. The inputs that need to be discussed further especially related with the market access. How to open bigger market for organic products, and how the agricultural inputs (feedstuffs, fertilizers and permitted plant protection products as well as cleaning agents and additives used in food production) capital and labor; affecting the output markets.

Related with the farm leaders, SSM can also revealed how power is expressed in the situation (Checkland and Poulter, 2006). Khisty (1995) stated that issues relating to the attainment of power, how it is manifested, and its evolution can be examined using SSM. Based on the discussion, it obvious that the farms had the dominant power in the system by having the financial, human, and area resources (from the government). It was also clear that large-scale farmers have more power than small-scale farmers due to financial and resources domination. Farm itself should have the power to manage the collaboration between small and large farmers, to prevent conflicts due to resource gaps. Partnership model should be built at farm level, especially on the area of optimizing organic quality, maintaining organic certification, improving farm documentation, facilitating and improving access to cooperative processing and marketing, facilitating local community support to organic farming and improving marketing of organic foods (Popov, 2014).

As suggested and defined by Checkland and Poulter (2006), the researcher can also use SSM to examine the roles, norms, and values of the multiple stakeholders in the system. Based on the discussion, Farm values may lie on transparency decision making, good interaction with the farmers, and focus on interaction, not only on profit making. The farmers on the other hand, may expect farm to display professional business skills, and give appreciation for small farmers.

This research successfully brought together multiple stakeholders who possessed different views on the problem that arise in the farm. Problem structuring is significant in SSM and assists stakeholders in challenging their worldviews (Winter, 2006). Through stakeholders' analysis, stakeholders were provided with the opportunity to jointly decide which issues to address to bring about improvement in farm. This improvement process can be listed to be done through in-depth discussion between stakeholders.

It was evident that stakeholders had engaged in learning, which according to Khisty (1995) is a central part of the SSM. Apart from the success part of the SSM, this research has several limitations. The limitation of SSM in not being able to bring about action in such a situation with the described stakeholder dynamics can be better comprehended using Jackson's System of Systems Methodology (SOSM) grid (Warren, 2002). Another limitation in this research was that the decision makers from the farm, could not be present, thus preventing a firm commitment to taking further action. Checkland and Poulter (2006) outline the reality of not always being able to include senior people in SSM investigations because of their demanding schedules.

\section{Managerial Implications}

Based on the research result, too many people involved in the farms might not good for the business especially in terms of efficiency. One hauler to distribute organic products is enough to support the farms. Too many people also cause conflict to arise, due to different 
perception of communication. The conflict arises in farms might affect the quality of the products. The farms must set a new human resource policy to make the operational process run effectively and efficiently.

\section{CONCLUSIONS AND RECOMMENDATIONS}

\section{Conclusions}

This research used SSM to organize system thinking in a complex situation where multiple humans interacts. Hard issues such as horticulture product quality, horticulture products supply, and certification issues, were successfully identified, as well as soft issues such as communication, norms and power. SSM tools were developed to let stakeholders describe the problems and discuss the improvement. This research mentioned the importance of the stakeholders' involvement, especially those with power and decision-making abilities, to bring the action resulted from this SSM process. Limitations in the research include: (a) getting participants to take active discussion part, (b) getting participants to have an honest dialogue, and (c) getting participants to discuss organizational dynamics.

\section{Recommendations}

Based on the research result, it is important for the farm to provide more transparency to the farmers especially related to the financial activities. For future research, it would be useful to try to get more active participants into the discussion and more stakeholders to be involved.

\section{ACKNOWLEDGEMENT}

The writer would like to thank all staffs in Agatho Farm Cisarua and Indonesia Organic Alliances that were involved in the research. This research was done with the support from Southeast Asian Regional Center for Graduate Study and Research in Agriculture

\section{REFERENCES}

Allen W, Kilvington, M. 2010. Stakeholder analyses. In book: Hatched, Chapter: Stakeholder Analysis, Publisher: Landcare Research.

Amekawa Y. 2010. Towards sustainable agriculture in the developing world: Theoretical perspectives and empirical insights [disertation]. USA: Iowa State University.

Bahar Y. 2007. Keberhasilan dan kinerja agribisnis hortikultura 2006. http://hortikultura.go.id. [28 March 2019].

[BIOCert] Badan Sertifikasi Organik Indonesia. 2018. http://www.biocert.co.id. [2 January 2018].

Brenton K. 2007. Using soft systems methodology to examine communication difficulties. Mental Health Practice 10(5): 12-16. https://doi. org/10.7748/mhp.10.5.12.s18.

Checkland P. 1985. Desirable and feasible change: An application of Soft Systems Methodology. The Journal of the Operational Research Society 36(9): 821-831. https://doi.org/10.1057/ jors.1985.148.

Checkland P, Poulter J. 2006. Learning for action: A short definitive account of Soft Systems Methodology and its use for practitioners, teachers and students. Chichester, United Kingdom: Wiley.

David W, Ardiansyah. 2016. Organic agriculture in Indonesia: challenges and opportunities. Organic Agriculture 7(3): 329-338. https://doi 10.1007/ s13165-016-0160-8.

Hammond D, Luiz J. 2016. The co-operative model as a means of stakeholder management: an exploratory qualitative analysis. South African Journal of Economic and Management Sciences 19(4): 630-646. https://doi.org/10.4102/sajems. v19i4.1537.

Hani E, Tamam M. 2016. Stakeholder Response to the Development Strategy of Sugarcane Dry Land Agriculture in East Java. Agriculture and Agricultural Science Procedia 9:469-474. https://doi.org/10.1016/j.aaspro.2016.02.165.

Indriana H, Kinseng R, Adriana G. 2016. Dinamika kelembagaan pertanian organik menuju pembangunan berkelanjutan. Sodality: Jurnal Sosiologi Pedesaan 4(2): 192-207.

Indonesian Central Bureau of Statistic. 2015. Luas lahan menurut penggunaan. Jakarta: BPS.

Kennon N, Howden P, Hartley M. 2009. Who really matters? A stakeholder analysis tool. Extension Farming Systems Journal 5(2).

Khisty C. 1995. Soft-systems methodology as learning and management tool. Journal of Urban Planning and Development 121(3): 91-107. https://doi.org/10.1061/(ASCE)07339488(1995)121:3(91). 
Missonier S, Loufrani-Fedida S. 2014. Stakeholder analysis and engagement in projects: From stakeholder relational perspective to stakeholder relational ontology. International Journal of Project Management 32(7): 1108-1122. https:// doi.org/10.1016/j.ijproman.2014.02.010.

Ndwandwe S, Weng R. 2018. Competitive analyses of the pig industry in Swaziland. Sustainability 10(12): 4402. https://doi.org/10.3390/ su10124402.

Parlyna R, Munawaroh M. 2011. Konsumsi pangan organik: Meningkatkan kesehatan konsumen?. Jurnal Ilmiah Econosains 9 (2): 157-165. https:// doi.org/10.21009/econosains.0092.06.

Popov V. 2014. Partnership of organic farming, eco-tourism and wilderness conservation experiences of the pilot project 'New Thracian Gold' in Bulgaria. Practitioners' Track, IFOAM Organic World Congress 2014, 'Building Organic Bridges', 13-15 Oct., Istanbul, Turkey.

Proches CN, Bodhanya S. 2015. An application of soft systems methodology in the Sugar Industry. International Journal of Qualitative Methods 14(1): 1-15. https://doi. org/10.1177/160940691501400101.

Ristianingrum A et al. 2016. Optimalisasi keberlanjutan pengembangan usaha padi organik di Kabupaten Cianjur, Jawa Barat. Jurnal Manajemen dan Agribisnis 13(1): 37-49. https://doi. org/10.17358/JMA.13.1.37.

Riswan R, Suyono E, Mafudi M. 2017. Revitalization model for village unit cooperative in Indonesia. European Research Studies XX (4A): 102-143.

Stefan A, Paul L. 2008. Does it pay to be green? A systematic overview. Academy of Management Perspectives 22(4): 45-62. https://doi. org/10.5465/amp.2008.35590353.

Tavella E, Hjortsø C. 2012. Enhancing the design and management of a local organic food supply chain with soft systems methodology. International Food and Agribusiness Management Review 15(2): 47-68.

Toor, S. 2010. Beyond the 'iron triangle': stakeholder perception of key performance indicators (KPIs) for large-scale public sector development projects. International Journal of Project Management 28(3): 228-236. https://doi. org/10.1016/j.ijproman.2009.05.005.

Tsouvalis C, Checkland P. 1996. Reflecting on SSM: the dividing line between 'real world' and 'systems thinking world'. Systems Research 13(1): $\quad 34-45 . \quad$ https://doi.org/10.1002/ (SICI) 1099-1735(199603)13:1<35::AIDSRES73>3.0.CO;2-O.

Vairo D, Häring A, Dabbert S, Zanoli R. 2009. Policies supporting organic food and farming in the EU: assessment and development by stakeholders in 11 European countries. Journal of International Food\&AgribusinessMarketing21(2-3):214-227. https://doi.org/10.1080/08974430802589733.

Varvasovsky Z, Brugha R. 2000. How to do (or not to do) A stakeholder analysis. Health Policy and Planning 15(3): 338-345.https://doi. org/10.1093/heapol/15.3.338.

Waney N, Soemarno Y, Yuliaty Y, Polii B. 2014. Developing indicators of sustainable agriculture at farm level. IOSR Journal of Agriculture and Veterinary Science 7: 42-53. https://doi. org/10.9790/2380-07224253.

Warren L. 2002. Total systems intervention. http:// www.eolss.net/samplechapters/c02/E6-46-0209.pdf. [2 January 2018].

Winter M. 2006. Problem structuring in project management: an application of soft systems methodology. The Journal of the Operational Research Society 57(7): 802-812. https://doi. org/10.1057/palgrave.jors.2602050. 